\title{
The sedimentary record of the last glaciation in the western Bellingshausen Sea (West Antarctica): Implications for the interpretation of diamictons in a polar-marine setting
}

\author{
C.-D. Hillenbrand $d^{\mathrm{a}, *}$, A. Baesler ${ }^{\mathrm{b}, 1}$, H. Grobe ${ }^{\mathrm{b}}$ \\ ${ }^{a}$ British Antarctic Survey, High Cross, Madingley Road, Cambridge CB3 OET, United Kingdom \\ ${ }^{\mathrm{b}}$ Alfred Wegener Institute for Polar and Marine Research, P.O. Box 1201 61, D-27515 Bremerhaven, Germany
}

Received 21 September 2004; received in revised form 23 December 2004; accepted 17 January 2005

\begin{abstract}
Upper Quaternary marine sediments recovered from the West Antarctic continental margin are characterized by a distinct lithological succession allowing the reconstruction of past environmental changes. Massive, homogenous diamictons were deposited elsewhere on the margin during the last glacial period, when grounded ice masses advanced across the shelf. Sedimentological investigations using a multi-proxy approach and examination of the margin topography suggest that during this time a deformation till and subsequently a glaciomarine till were deposited on the shelf, while glaciogenic debris flows were deposited on the slope and rise. The comparison of the clay mineral assemblages in the matrix of the diamictons with clay mineral assemblages of potential source areas reveals distinct pathways of grounded ice flow on the shelf. Lithogenic sandy muds overlying the diamictons were deposited by meltwater flows and/or marine currents on the shelf, and by turbidity currents and marine currents on the slope and rise, respectively. The sedimentation of the sandy muds denotes a deglaciation stage, when grounded ice started to retreat from the shelf, but semi-permanent sea-ice coverage still hampered biological productivity. Bioturbated, foraminifer-bearing sediments were deposited in a glaciomarine setting during the present interglacial period, when sea-ice cover was only seasonally present and a marine current related to the southern boundary of the Antarctic Circumpolar Current winnowed the seafloor on the outer shelf, slope and rise.
\end{abstract}

(C) 2005 Elsevier B.V. All rights reserved.

Keywords: Antarctica; Bellingshausen Sea; clay mineralogy; continental margin; debris flow; till

* Corresponding author. Tel.: +44 1223 221340; fax: +44 1223 221646.

E-mail address: hilc@bas.ac.uk (C.-D. Hillenbrand).

${ }^{1}$ Present address: Lessingstrasse 7, D-45657 Recklinghausen, Germany.

\section{Introduction: diamictons in polar-marine settings and their recognition}

The sedimentological interpretation of diamictons recovered in cores in polar marine settings is an important task in marine geology. A diamicton may 
have been deposited (1) as a subglacial till by slowly flowing grounded ice (lodgement till=LT) or by a fast flowing ice stream (deformation till=DT; e.g. Anderson, 1999), (2) as a glaciomarine till (= GT) deposited under a floating ice shelf proximal to its grounding line or by concentrated iceberg rafting along the calving line of a receding ice shelf (e.g. Domack et al., 1999), (3) as an iceberg turbate (= IT) resulting from the reworking and redeposition of glacial(-marine) shelf sediments by iceberg grounding (e.g. Lowe and Anderson, 2002), or (4) as a glaciogenic debris flow deposit (= GDF; e.g. King et al., 1998). Here we use the term "glaciogenic debris flow" in the broader sense of King et al. (1998) encompassing deposits from slides, slumps, and debris flows in a glaciomarine setting. Formation mechanisms of these types of diamictons were described in detail by Vorren et al. (1984), Kellogg and Kellogg (1988), Sættem et al. (1992), Domack et al. (1998), and Anderson (1999).

An unambiguous interpretation of diamictons in a glaciomarine setting often requires that either the diamictons cored in a particular study area represent a whole suite of these different depositional mechanisms, thus allowing direct comparison of distinct relative sedimentological differences between them (e.g. Domack et al., 1998, 1999; Licht et al., 1999; Eyles et al., 2001; Evans and Pudsey, 2002; Evans et al., 2005 ), or that additional information about the sedimentary process is available, such as high-resolution acoustic subbottom profiles and/or swath-bathymetric maps showing distinct seafloor bedforms (e.g. Pudsey et al., 1994, 2001; Shipp et al., 1999; Wellner et al., 2001; Lowe and Anderson, 2002; Ó Cofaigh et al., 2002; Dowdeswell et al., 2004a; Evans et al., 2005).

In the literature, most authors distinguish a LT from a DT or GT by its higher shear strength $(>50 \mathrm{kPa})$, higher density, and lower porosity (e.g. Anderson, 1999; Wellner et al., 2001; Evans et al., 2005; Ó Cofaigh et al., 2005). The characteristics given for a DT and a GT, however, were also described for GDFs on the Norwegian continental margin (see King et al., 1998; Laberg et al., 2002), thus the sedimentological distinction between DT, GT, and GDF is even more complicated (e.g. Kurtz and Anderson, 1979). A GT may differ from a DT and GDF by the higher content, better preservation, and/or the composition of the biogenic material, internal stratification/lamination, gradational upper and lower boundaries, variability of sedimentological parameters (such as mineralogical composition, water content, content of total organic carbon, grain-size distribution), intercalation of tephra layers, regular chronolgical order of radiocarbon ages, and lack of microfabric caused by subglacial deformation and lack of pebble fabric generated by mass wasting processes, respectively (Kurtz and Anderson, 1979; Domack et al., 1998, 1999; Licht et al., 1999; Eyles et al., 2001; Wellner et al., 2001; Lowe and Anderson, 2002; Evans and Pudsey, 2002; Scherer et al., 2004; Evans et al., 2005; Ó Cofaigh et al., 2005). Most of these criteria, however, are neither mandatory (e.g. stratification/lamination, abundance of tephra layers, regular chronological order, gradational contacts) nor quantitatively well constrained (e.g. "higher" contents and "better" preservation of biogenic components).

Diamictons overlain by a pelletized/granulated unit were observed in some sediment cores recovered from various shelf areas around Antarctica (Domack et al., 1999; Lowe and Anderson, 2002; Evans et al., 2005). The authors interpreted this sequence to represent the transition of a LT (or DT) to a GT with the pelletized "lift-off" unit deposited when the formerly grounded ice started to float, and thus basal debris melted out directly at the grounding line of an ice shelf. However, a very similar facies succession was also observed in cores recovered from the slope of the North Sea Trough Mouth Fan, there representing the transition of GDF deposition to hemipelagic-glaciomarine sedimentation (King et al., 1998). Because an IT comprises characteristics usually attributed to a DT or a GDF, such as low shear strength, massive structure, and lack of chronostratigraphical order (Kellogg and Kellogg, 1988; Lowe and Anderson, 2002), its identification ultimately requires additional information about the spatial extent of the deposit and/or the abundance of iceberg scours close to the core location.

Most reconstructions of the size and shape of the Antarctic ice sheets during the last glacial maximum (LGM) and of the retreat of ice masses from the Antarctic shelf after the LGM are based on the mapping of geomorphic bedforms (e.g. Wellner et al., 2001; Anderson et al., 2002; Canals et al., 2002; Ó Cofaigh et al., 2002). The processes responsible for the formation of these features are often inferred from the sediments recovered from the bedforms (e.g. Domack et al., 1999; 
Shipp et al., 1999; Lowe and Anderson, 2002; Evans et al., 2005; Ó Cofaigh et al., 2005). A cored diamicton, and thus its related geomorphic feature, is attributed to a particular subglacial or glaciomarine setting despite the sedimentological difficulties in interpreting its origin. The conclusions based on past changes in icesheet configurations have far-reaching consequences regarding the assessment of "natural" sea-level rise after the LGM (Bindschadler, 1998; Domack et al., 1999; Licht, 2004). Therefore, it is important to find sedimentological criteria for differentiation of diamictons in glacial to glaciomarine settings. In this paper, we will demonstrate how the depositional mechanisms of Upper Quaternary diamictons recovered from the West Antarctic continental margin in the Bellingshausen Sea can be deduced mainly from their shear strength, clast content, clay mineralogical composition of the matrix, and seafloor topography. Furthermore, we will show how the pattern of deglaciation after the LGM and changes in glaciomarine deposition during the present interglacial were archived in the sedimentary record on the margin.

\section{Sediment cores and regional setting}

Gravity cores were recovered from the western Bellingshausen Sea in the Pacific sector of the Southern Ocean (Fig. 1a,b) during RV Polarstern cruise ANT-XI/3 (Miller and Grobe, 1996). Surface sediment samples for clay mineral analyses were recovered both during cruise ANT-XI/3 and RRS James Clark Ross cruise JR104 (Larter et al., 2004). Core PS $2538\left(69^{\circ} 43.8^{\prime} \mathrm{S}, 88^{\circ} 55.4^{\prime} \mathrm{W}, 3238\right.$ $\mathrm{m}$ water depth, $4.15 \mathrm{~m}$ core recovery) was recovered from the continental rise, while core

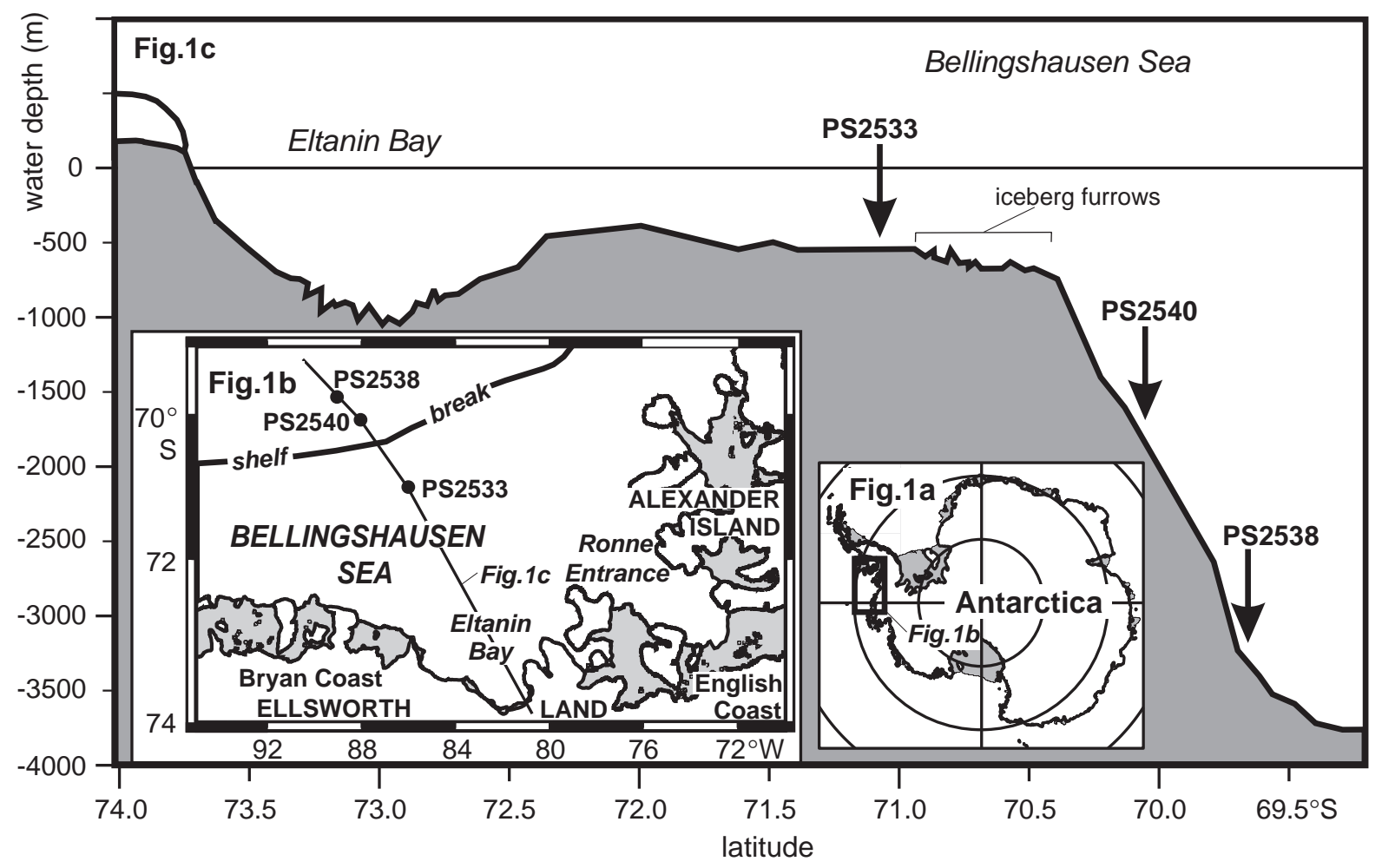

Fig. 1. Study area. (a) Study area within the broader context of Antarctica. (b) Map of the study area with gravity core sites and locations mentioned in the text. Ice shelves are grey shaded, shelf break is shown by the thick black line, and profile of Figure 1c is depicted by the thin black line. (c) Bathymetric profile across the continental margin in the western Bellingshausen Sea with locations of gravity cores and iceberg furrows on the outer shelf (redrawn after Miller and Grobe, 1996). 
PS2540 $\left(70^{\circ} 03.9^{\prime} \mathrm{S}, 87^{\circ} 55.4^{\prime} \mathrm{W}, 1820 \mathrm{~m}\right.$ water depth, $4.14 \mathrm{~m}$ core recovery) was recovered from the broad, gently dipping $\left(1^{\circ}-2^{\circ}\right)$, and glacially prograded continental slope (Nitsche et al., 1997) (Fig. 1c).

The gentle dip of the slope in the study area is quite unusual for the West Antarctic continental margin. The upper slope may form part of a broad sediment ridge centred between $85^{\circ} \mathrm{W}$ and $87^{\circ} \mathrm{W}$ (Nitsche et al., 2000). Core PS2533 $\left(71^{\circ} 01.5^{\prime} \mathrm{S}\right.$, $85^{\circ} 53.9^{\prime} \mathrm{W}, 588 \mathrm{~m}$ water depth, $1.93 \mathrm{~m}$ core recovery) was recovered from the ca. $400 \mathrm{~km}$ wide shelf. North of the ca. $1000 \mathrm{~m}$ deep trough in Eltanin Bay the shelf gently dips from $390 \mathrm{~m}$ water depth down to $682 \mathrm{~m}$ water depth at the shelf break (Fig. 1c). With its average seaward inclination of $0.08^{\circ}$, the shelf profile in the study area is atypical for the Antarctic shelf (e.g. Anderson, 1999).

Besides the Ross Sea and the Weddell Sea, the Bellingshausen and Amundsen seas represent the third main drainage route for the chiefly marine-based West Antarctic Ice Sheet (WAIS). The glacial drainage systems along the Pacific margin of West Antarctica are important because they make up $>40 \%$ of the grounded area of the WAIS. In the western Bellingshausen Sea, the ice drainage is performed by smallsized ice shelves confined to the English Coast and the western Bryan Coast, and glaciers with very small ice tongues flowing into Eltanin Bay (Fig. 1b).

Surface water currents on the shelf of the study area are driven by the westward "Antarctic Coastal Current" (CAC). Thereby, current speed seems to be higher over the shelf break and slope because of the presence of an oceanographic front, the "southern boundary of the Antarctic Circumpolar Current (ACC)" (Orsi et al., 1995; Hillenbrand et al., 2003). Surface and deep water masses north of this front are located within the clockwise flowing ACC (see Fig. 1 in Hillenbrand et al., 2003). In contrast, bottom water flow on the upper continental rise obviously is affected by a westward current (Hillenbrand et al., 2003 and references therein). At present, upwelling of relatively warm Circumpolar Deep Water (CDW) takes place at the continental margin, and CDW locally protrudes far onto the shelf, where it causes intense basal melting of ice shelves (Jacobs et al., 1996).

\section{Methods}

Physical properties (magnetic susceptibility, wet bulk density, and P-wave velocity) were measured on whole cores using a GEOTEK multisensor core logger (MSCL). Magnetic susceptibility was additionally measured on split cores with a BARTINGTON MS2E point sensor and corrected for unrepresentative susceptibility values caused by single pebbles or cobbles in the sediment. Shear strength was measured on the split cores using a shear vane HAAKE Rotovisco $1500 \mathrm{M}$. Concentrations of gravel grains and pebbles were determined on X-radiographs of 1 $\mathrm{cm}$ thick and $10 \mathrm{~cm}$ wide sediment slices by counting the clasts $>2 \mathrm{~mm}$ in each centimeter core depth (Grobe, 1987).

Individual sediment samples were taken from the sediment cores at intervals of 5 to $15 \mathrm{~cm}$ core depth. Water content and dry bulk density were measured on a freeze-dried and pulverized bulk sediment sample of $5 \mathrm{~cm}^{3}$ volume. Also, contents of total organic carbon (TOC) and $\mathrm{CaCO}_{3}$ were determined on this subsample using an element analyzer LECO CS-125. Another sub-sample of $5 \mathrm{~cm}^{3}$ volume was treated with $3 \%$ hydrogen peroxide solution and $10 \%$ acetic acid, to disaggregate it and remove TOC and $\mathrm{CaCO}_{3}$, and then washed through a $2 \mathrm{~mm}$ and a $63 \mu \mathrm{m}$ mesh in order to separate gravel and sand from silt and clay. Silt and clay were separated at $2 \mu \mathrm{m}$ in settling tubes. The proportions of the sand, silt, and clay fractions were determined on a weight basis. Relative clay mineral contents were determined with X-ray diffraction on texturally orientated clay aggregates according to the methods described in detail by Ehrmann et al. (1992) and Petschick et al. (1996).

Upper Quaternary sedimentary sequences recovered on the West Antarctic continental margin between ca. $80^{\circ} \mathrm{W}$ and ca. $120^{\circ} \mathrm{W}$ show a systematic up-core increase of the $\mathrm{CaCO}_{3}$ contents in their younger parts (Hillenbrand et al., 2003). This pattern can be used for a lithostratigraphic correlation of the cores from the western Bellingshausen Sea with a gravity core from the Amundsen Sea (cf. Hillenbrand et al., 2003), for which an age model mainly based on foraminiferal oxygen isotope stratigraphy was established (Hillenbrand et al., 2002, 2003). This age model was used as a reference to identify the marine isotope stage boundary $2 / 1$. Accordingly, the up-core increase in 
$\mathrm{CaCO}_{3}$ contents is interpreted to have begun at about 12 ka B.P. (Fig. 2; cf. Hillenbrand et al., 2003).

All data are available under http://www.pangaea. de/home/chillenbrand.

\section{Results: lithological succession}

The basal lithological unit of all cores is formed by grey, homogenous diamictons (Fig. 2), which are assumed to be deposited during the last glacial period. Based on fluctuations of several sedimentological parameters (see below), the diamicton in core PS2533 can be subdivided into a lower diamicton $(1.93 \mathrm{~m}$ to $0.90 \mathrm{~m}$ core depth) and an upper diamicton $(0.90 \mathrm{~m}$ to $0.46 \mathrm{~m}$ core depth) (Fig. 2c), with the interval between $0.80 \mathrm{~m}$ and $0.64 \mathrm{~m}$ core depth light-grey coloured. In core PS2540, the top section of the diamicton (uppermost $6 \mathrm{~cm}$ ) exhibits olive-grey and olive laminae.

The water contents in the diamictons of cores PS2538 and PS2540 decrease gradually, but continuously with core depth (Fig. 2a,b). This decrease is accompanied by a corresponding gradual downcore increase of the dry and wet bulk densities. The same trend with some variability within the upper diamicton is observed in core PS2533 (Fig. 2c). In all cores, the shear strength of the diamictons increases downcore from values around $5 \mathrm{kPa}$ to values up to $>20 \mathrm{kPa}$. While this increase occurs rather smoothly in cores PS2538 and PS2540, a major shift in shear strength is observed at $0.90 \mathrm{~m}$ in core PS2533. The lower sections of all diamictons exhibit maxima in shear strength with a uniform decrease towards the core base (Fig. 2). This consistent trend may indicate that other lithological units underlie the diamictons preventing deeper penetration of the gravity corer into the seabed at all three sites.

Within the diamictons of cores PS2538 and PS2540, values of magnetic susceptibility are rather constant, at about $170 * 10^{-5}$ SI units with local maxima likely to be caused by mafic lithoclasts embedded in the diamictons (Fig. 2a,b). In core PS2533 magnetic susceptibility values below $0.80 \mathrm{~m}$ are on average $120 * 10^{-5}$ SI units, lower than in the diamictons of the other cores (Fig. 2c). The $\mathrm{CaCO}_{3}$ and TOC contents within all diamictons mainly vary around 1 wt.\% and 0.1 wt. $\%$, respectively. Some variability of TOC contents $(0.1-0.2 \mathrm{wt} . \%)$ is observed in the upper diamicton of core PS2533 (Fig. 2c).

The concentration of clasts $>2 \mathrm{~mm}$ in the diamictons of cores PS2538 and PS2540 exhibits only some weak trends (Fig. 2a,b). At site PS2533, however, a minimum in the clast content is observed between $0.80 \mathrm{~m}$ and $0.64 \mathrm{~m}$ core depth (Fig. $2 \mathrm{c}$ ). The sand-silt-clay ratios of the diamictons underline their unsorted texture by exhibiting almost no variability, neither within a single core nor between the different cores. The homogeneity within each diamicton is also reflected by the clay mineral distribution. The most pronounced discrepancy between the diamictons arises when considering the contents of illite and smectite, respectively. The diamictons on the slope and rise contain $40 \%$ illite and $28 \%$ smectite (Fig. $2 \mathrm{a}, \mathrm{b})$, whereas both the lower and the upper diamicton deposited on the shelf contain $60 \%$ illite and $9 \%$ smectite (Fig. 2c).

In all cores, the diamictons are overlain by olive grey, slightly bioturbated lithogenic sandy muds (Fig. 2). In cores PS2538 and PS2540, the sandy muds additionally exhibit slight stratification and normal grading at their base (Fig. 2a,b). Shear strength, wet, and dry bulk densities and magnetic susceptibility generally decrease from base to top within the sandy muds, whereas the water contents increase. Peaks in shear strength originate in the intercalation of discrete sandy to silty layers. In cores PS2538 and PS2540, sand and silt are highest at the base of the sandy mud unit, where contents of smectite are at their maximum, too (Fig. 2a,b). In contrast, smectite contents slightly increase upwards within the sandy mud of core PS2533 (Fig. 2c). Gravel and pebble contents show some variations in all sandy muds, but in general the average clast concentration is lower than both in the underlying and overlying sediments. Also, the $\mathrm{CaCO}_{3}$ and TOC contents are at their minimum within the sandy mud (Fig. 2).

The top lithological unit in all cores is formed by brown, slightly bioturbated foraminifer-bearing mud, foraminiferal mud, and foraminiferal ooze (Fig. 2). The $\mathrm{CaCO}_{3}$ contents are highest in this interval (up to 28 wt.\%) as a consequence of the high concentrations of planktonic foraminifera (Neogloboquadrina pachyderma sinistral). The TOC and water contents show relative maxima at the sediment surface, whereas shear strength, wet, and dry bulk densities and magnetic 


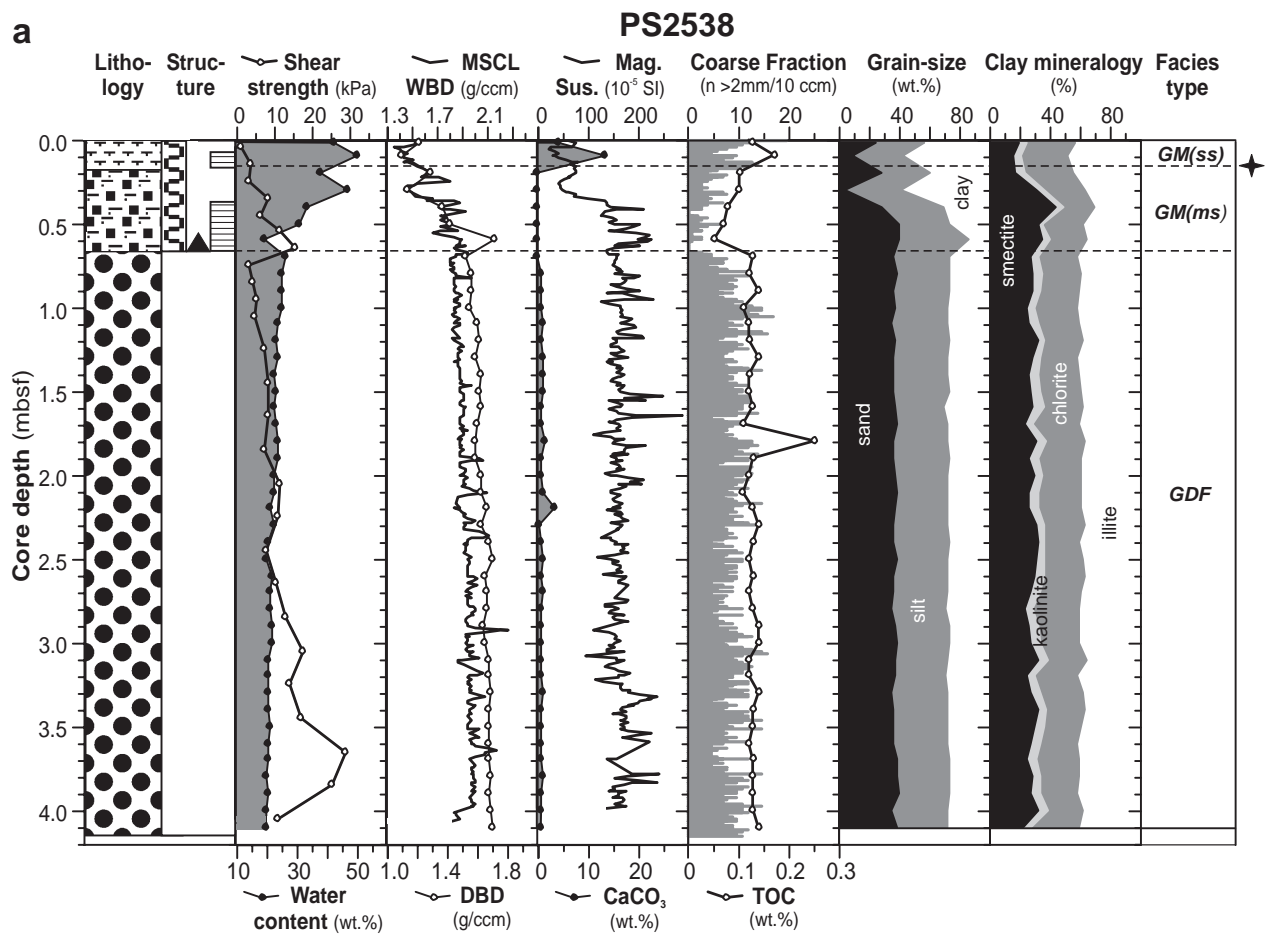

b

PS2540

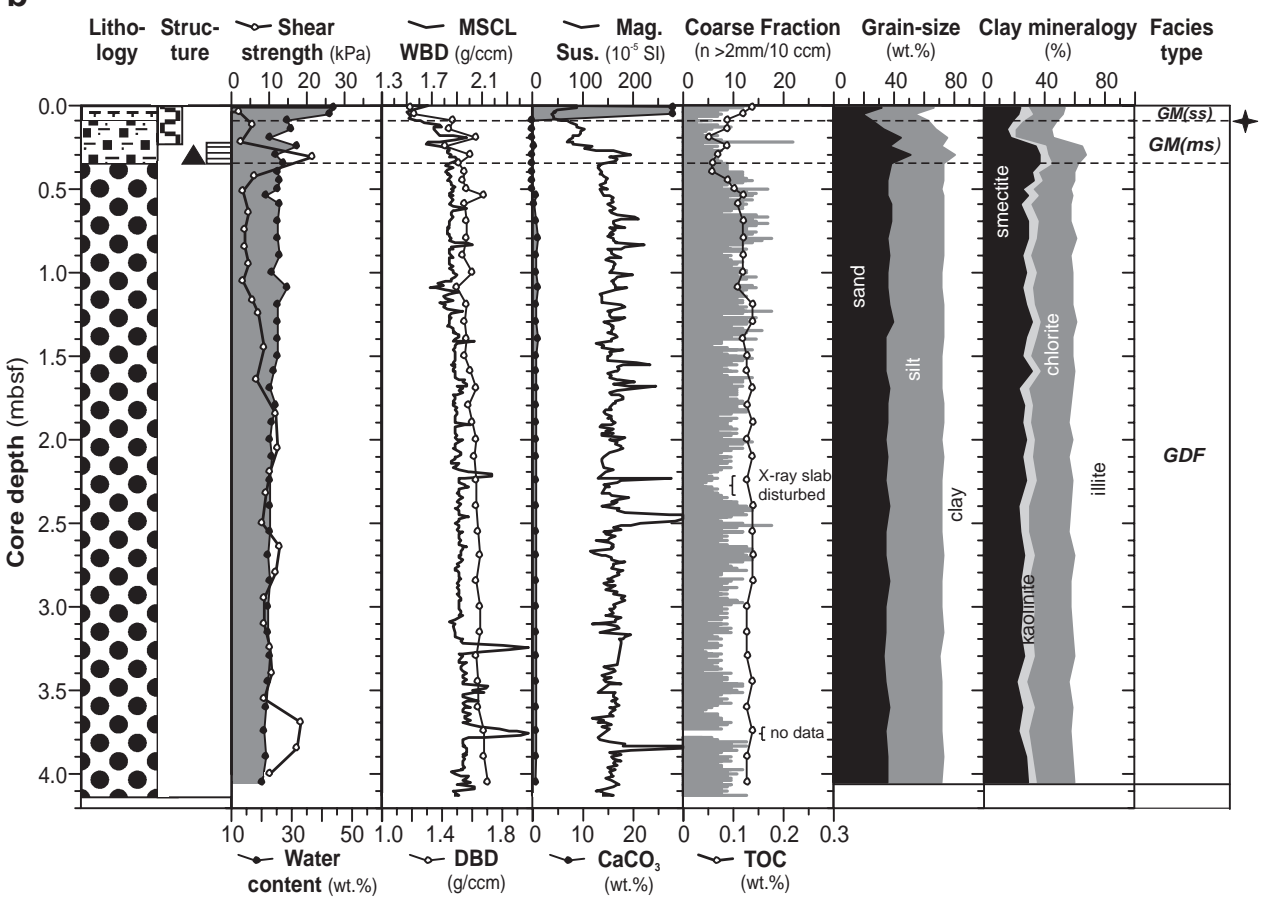




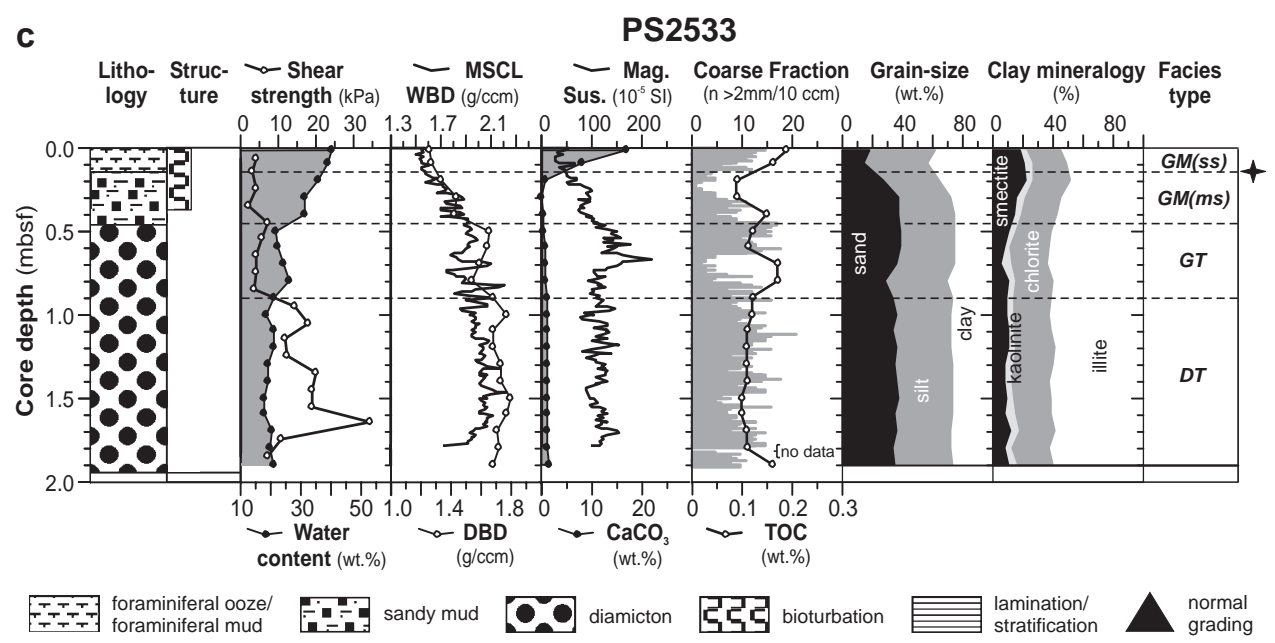

Fig. 2. Sedimentological parameters and facies types. Lithology, structure, shear strength, water content, wet bulk density (measured with the multisensor core logger, MSCL WBD), dry bulk density (DBD), magnetic susceptibility (measured with a point sensor), contents of $\mathrm{CaCO}_{3}$, coarse fraction ( $>2 \mathrm{~mm}$ ), contents of total organic carbon (TOC), grain-size distribution, clay mineral contents and interpreted facies type of sediments recovered at sites PS2538 (a), PS2540 (b) and PS2533 (c) in the western Bellingshausen Sea. Stars mark an approximate age of 12 ka B.P. based on the lithostratigraphic correlation with a sediment core from the Amundsen Sea (cf. Hillenbrand et al., 2003). DT: deformation till; GT:glaciomarine till; GDF: glaciogenic debris flow; GM: glaciomarine mud; ms: multiyear sea-ice coverage; ss: seasonal sea-ice coverage.

susceptibility decrease to their lowest values. Contents of gravel and lithogenic sand increase towards the sediment surface. The clay mineralogy of this unit is characterized by a minor increase of smectite, which is accompanied by an additional increase of chlorite in core PS2538 (Fig. 2a).

\section{Discussion}

\subsection{Glacial deposition of deformation till and} glaciogenic debris flows resulting from grounded ice advance across the shelf

Taking account of the deep water setting of the core locations, we preclude the diamictons on the slope and rise to result from iceberg ploughing, subglacial deposition, or glaciomarine sedimentation proximal to the grounding line of an ice shelf (cf. Kurtz and Anderson, 1979). Their structural and mineralogical homogeneity make a deposition by icebergs concentrated along the front of an ice shelf hanging over the slope unlikely, because such diamictons are usually identified by their stratification (Domack et al., 1998) and/or mineralogical heterogeneity (Domack et al., 1999). Thus, the diamictons of cores PS2538 and PS2540 must represent GDFs. This interpretation is corroborated by the finding of acoustically-transparent sediment lenses typifying debris flow deposits in subbottom profiles on the slope of the study area (Ó Cofaigh et al., 2004, submitted for publication). The debris flows are likely to have originated in the delivery of huge amounts of unsorted glaciogenic debris to the shelf edge during glacial periods, when grounded ice masses had advanced across the shelf (cf. Dowdeswell et al., 2004b). The question arises whether or not the lower and upper diamictons in core PS2533 were deposited by debris flows, too. The enrichment of illite in the diamictons on the shelf clearly documents that these units do not correspond to the sedimentologically uniform GDFs recovered from the slope and rise (Fig. 3).

Although the triggering of submarine debris flows is normally considered to require slope angles steeper than $1^{\circ}$ (Stow, 1994), GDFs have been reported on slopes as gentle as $0.2^{\circ}-0.8^{\circ}$ from the NorwegianBarents Sea continental margins (Laberg and Vorren, 2000; Nygård et al., 2002). The initiation of the GDFs on this margin also resulted from instability arising from high sedimentation rates on the upper continental slope, which were related to the input of 


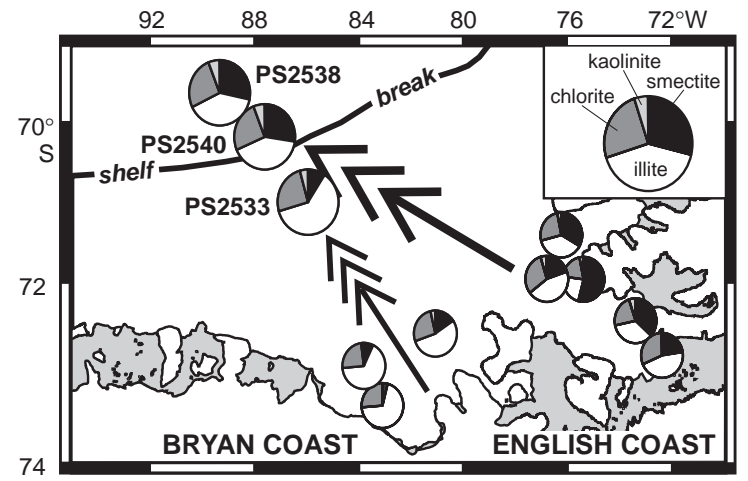

Fig. 3. Spatial distribution of clay mineral assemblages. Sketch map with clay mineral assemblages in surface sediments proximal to the coast (small pie charts) and average clay mineral assemblages within the diamictons at sites PS2538, PS2540 and PS2533 (big pie charts). Arrows denote reconstructed palaeo-ice flow lines during the last glacial period.

glaciogenic debris by ice streams during periods of maximum ice advance (e.g. Elverhøi et al., 1997; Laberg and Vorren, 2000; Nygård et al., 2002). Debris flows can even occur on slopes with gradients as low as $0.05^{\circ}$ (Schwab et al., 1996; Gee et al., 1999), but the suggested flow mechanisms on such gentle slopes require very special pre-conditions, such as loading and mobilization of basal volcaniclastic sands.

The slight oceanward inclination of the shelf in the western Bellingshausen Sea $\left(<0.1^{\circ}\right)$ is probably too gentle to trigger sediment gravity flows, suggesting that the diamictons at site PS2533 were deposited as tills by an ice mass, which had advanced northward across the shelf during the last glacial period. The low shear strength of the diamictons precludes their deposition as LT. Furthermore, an area with irregular seafloor topography, which is visible in the subbottom profiler data (Fig. 1c) and likely to result from intense iceberg furrowing, is clearly located seaward of site PS2533. The position of the core site south of the intensely scoured outermost shelf as well as a confinement of iceberg furrows to water depths less than $460 \mathrm{~m}$ and greater than $590 \mathrm{~m}$ on the outer shelf of the study area (Ó Cofaigh et al., 2004), thus excluding the water depth of site PS2533, indicate that the diamictons in this core are unlikely to represent ITs. This conclusion is corroborated by the uniform texture of the diamictons, because ITs may be enriched in sand (e.g. Lowe and Anderson, 2002). Compared to the upper diamicton, the lower diamic- ton in core PS2533 exhibits significantly higher shear strength, higher clast content, and generally less variability of wet and dry bulk densities and magnetic susceptibility (Fig. 2c). Therefore, we interpret the lower diamicton at site PS2533 as a DT deposited by an ice stream. This interpretation is supported by multibeam records from the shelf of the study area showing mega-scale glacial lineations typifying former ice-stream pathways (Wellner et al., 2001; Ó Cofaigh et al., 2004, submitted for publication).

\subsection{Reconstruction of grounded ice-stream pathways based on clay mineralogical evidence}

Surprisingly, there is clear clay mineralogical evidence that the glaciogenic debris of the GDFs at sites PS2538 and PS2540 was not delivered by the same ice stream depositing the DT on the adjacent shelf (Figs. 3 and 4). This suggests different source areas and pathways for the lithogenic detritus. Unfortunately, in the largely ice-covered polar regions, geological information regarding the occurrence of potential rock types in the hinterland is often sparse. In the study area, such information is restricted to the English Coast and to Alexander Island (locations see Fig. 1). Along the English Coast outcrops of Cretaceous plutonic rocks, Jurassic volcanic rocks, Cainozoic basaltic rocks, and minor outcrops of Palaeozoic-Jurassic sedimentary rocks were reported (Laudon, 1991; Rowley et al., 1991; Smellie, 1999). The western part of Alexander

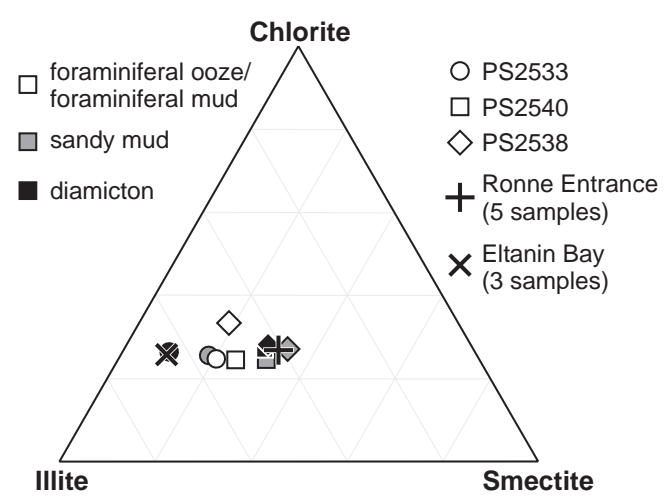

Fig. 4. Clay mineral assemblages in surface sediments and lithological units. Ternary diagram of average clay mineral assemblages in surface sediments proximal to the coast and average clay mineral assemblages within the different lithological units at sites PS2538, PS2540 and PS2533. 
Island includes extensive exposures of Cainozoic alkaline volcanic rocks (Smellie, 1999), whereas its eastern part comprises Mesozoic accretionary prism and forearc basin sequences intruded and unconformably overlain by arc/forearc igneous rocks (e.g. Doubleday et al., 1994; McCarron and Smellie, 1998).

The analysis of clay mineral assemblages in surface sediments recovered proximal to the coast may give important hints to particular source areas in the Antarctic hinterland, and thus may help to decipher transport pathways farther offshore (e.g. Hillenbrand and Ehrmann, 2002, 2003; Diekmann et al., 2003). The main clay mineral component in surface sediment samples from Eltanin Bay is illite, whereas surface sediments in Ronne Entrance contain more smectite, less illite, and similar contents of chlorite (Fig. 3; Hillenbrand et al., 2003). The dominance of illite in Eltanin Bay is likely to reflect the supply of detritus from plutonic rocks underlying the Bryan Coast, because clay mineral assemblages in soils formed on granitic rocks in Ellsworth Land mainly contain illite (Vennum and Nejedly, 1990). Furthermore, a similar clay mineral assemblage as observed in Eltanin Bay was found on the shelf north of Alexander Island and could be attributed to the supply of detritus derived from granitic and gneissic rocks cropping out in the huge Rouen Mountains batholith at the northern tip of this island (Hillenbrand and Ehrmann, 2002). The relative enrichment of smectite in the surface sediment samples in Ronne Entrance probably originates in the additional supply of lithogenic detritus derived from volcanic rocks cropping out on western Alexander Island and along the English Coast (Smellie, 1999). Soils formed on volcanic rocks at the English Coast were shown to differ from those formed on their granitic counterparts by higher contents of smectite (Vennum and Nejedly, 1990).

We consider that an ice stream advancing across the shelf would rework older sedimentary strata cropping out on the outer shelf (e.g. Wellner et al., 2001). When incorporated into the DT, the mineralogy of such old sediments, which may be pre-glacial in age (Palaeogene or older), would change the clay mineral assemblage delivered from the hinterland, e.g. by adding pedogenic smectite (Robert and Maillot, 1990). However, in the study area, the transition between crystalline bedrock and younger sediments is apparently located in Eltanin Bay (Wellner et al., 2001).
Moreover, in multichannel seismic profiles, there are no hints for submarine outcrops of old sedimentary strata between site PS2533 and the shelf break (Nitsche et al., 1997, 2000). Thus, the enrichment of smectite in the GDFs compared to the DT cannot be explained by glacial erosion of pre-glacial sediments on the outer shelf north of site PS2533.

The clay mineral assemblages deposited in the GDFs at sites PS2538 and PS2540 clearly correspond to that offshore from western Alexander Island/ English Coast, indicating that most detritus was supplied from there, whereas the assemblage in the DT at site PS2533 resembles that offshore from Bryan Coast (Fig. 4). This spatial relationship suggests that most recently grounded ice had advanced from Ronne Entrance up to the shelf break delivering huge amounts of glaciogenic debris down to the slope and rise, while the grounding line of the ice-stream tributary originating in Eltanin Bay was located somewhere between site PS2533 and the shelf edge (Fig. 3). This scenario, however, does not preclude the possibility that also the ice-stream tributary draining through Eltanin Bay had reached the shelf break during an earlier stage of the last glacial period.

\subsection{Glaciomarine depositional processes during the phase of deglaciation}

The upper diamicton at site PS2533 exhibits no significant clay mineralogical difference from the underlying DT, but shows an even lower shear strength, a very low clast content and generally higher variability of wet and dry bulk densities and magnetic susceptibility (Fig. 2c). Furthermore, its clast-poor interval contains calcareous benthic foraminifera belonging to the species Buliminia aculeata and Cassidulina biora, which were reported elsewhere from the Antarctic continental shelf with B. aculeata (Mackensen et al., 1990; Ishman and Domack, 1994) and C. biora (Igarashi et al., 2001) interpreted to indicate incursion of CDW. Alternatively, the occurrence of $C$. biora in Antarctic shelf sediments was attributed to a sub-ice shelf environment (Milam and Anderson, 1981) and/or to a habitat affected by strong marine currents ( $\mathrm{Li}$ et al., 2000).

Taking into account all sedimentological characteristics (low shear strength and clast content, variability of water content and densities, identical clay mineral- 
ogy to the DT, low concentration of biogenic material, presence of apparently autochthonous benthic foraminifera), we interpret the upper diamicton at site PS2533 as a GT deposited in association with a floating ice shelf. The GT probably formed during the phase of deglaciation, when the formerly grounded ice stream draining Eltanin Bay began to float and its grounding line retreated landward of the core site. The clast-rich, lower section of the GT is likely to have been deposited proximal to the grounding line, whereas the clast-poor, middle section of the GT probably formed mid-way between the grounding line and the ice front, in an area similar to the "null-zone" of Domack et al. (1999). We point out that this section of the upper diamicton at site PS2533 contains the autochthonous benthic foraminiferal species underlining its formation under an ice shelf (cf. Eyles et al., 2001), because an iceberg-rafted till usually bears mixed microfossil assemblages (Domack et al., 1998).

The significant increase of coarse-grained clasts towards the top section of the GT (Fig. 2c) might reflect the southward passage of the ice-shelf's calving line across the core site resulting in an enhanced supply of ice-rafted debris (IRD) by icebergs (cf. Domack et al., 1999). Thereby, we consider that, in contrast to polar settings on the northern hemisphere, sea ice plays a negligible role for the transport and deposition of IRD on the Antarctic continental margin because of the over-deepening of the shelf. According to Domack et al. (1998, 1999), an iceberg-rafted diamicton is characterized by variability in magnetic susceptibility and mineralogical heterogeneity, reflecting the variety of sources for the IRD. The upper section of the GT in core PS2533 exhibits higher values of magnetic susceptibility than below, but no significant variations in clay mineralogy (Fig. 2c). Regardless the precise depositional mechanism for the upper section of the GT at site PS2533, however, we conclude that the formation of the GT as a whole was related to the presence of an ice shelf.

The sandy mud units recovered in the western Bellingshausen Sea resemble lithological units observed on top of GDFs on the Antarctic slope in the Weddell and Ross seas (Kurtz and Anderson, 1979; Wright and Anderson, 1982) and at the Norwegian continental margin (King et al., 1998; Laberg et al., 2002). Their grain-size composition and their slight bioturbation clearly point to a glaciomarine depositional environment, with the dominance of lithogenic over biogenic detritus suggesting a multiyear sea-ice coverage. For site PS2533, a sub-ice shelf setting distal to the grounding line is unlikely because of bioturbation and significant contents of coarse-grained clasts interpreted as IRD (Fig. 2c). Considering that primary sedimentary structures may have been destroyed by later bioturbation, we suppose that the sandy mud unit at site PS2533 was deposited under a semipermanent sea ice cover by settling from suspension in buoyant meltwater plumes originating from the base of an ice shelf, which was located south of the core location, or by marine currents. The increase of smectite throughout the sandy mud unit at this location might document the enhanced input of fine-grained lithogenic detritus originating in Ronne Entrance via the CAC (Fig. 4), possibly in conjunction with CDW advection, and thus further retreat of grounded ice draining through Eltanin Bay.

The sedimentological homogeneity of the upper parts of the sandy muds indicates a hemipelagic depositional environment characterized by lowenergy currents, whereas lamination and normal grading at the base of the sandy muds in cores PS2538 and PS2540 (Fig. 2a,b) point to a deposition by turbidity currents. As indicated by their clay mineralogical composition (Fig. 4), the sandy muds at sites PS2538 and PS2540 have the same source as the underlying GDFs. Thus, the turbidity currents probably originated from GDFs deposited on the upper slope. Downslope transitions in the style of gravitational transport are well documented for the Antarctic continental margin (e.g. Wright and Anderson, 1982; Larter and Cunningham, 1993; Dowdeswell et al., 2004b). The deposition of the turbidites at sites PS2538 and PS2540 indicates either that the run-out distance of the GDFs was reduced because of a lower supply of glaciogenic debris to the shelf edge or that slope instability persisted for some time after the supply of glaciogenic debris had stopped. In each case, the deposition of the sandy mud units at all sites can be attributed to a phase of deglaciation in the western Bellingshausen Sea, when the supply of glaciogenic debris to the continental slope generally decreased in response to grounding line retreat on the shelf. 


\subsection{Accumulation of foraminifer-bearing sediments during the present interglacial period}

The bioturbated foraminiferal muds and oozes represent glaciomarine sediments deposited during the present interglacial period (Fig. 2). Only seasonally present sea-ice coverage allowed sunlight to penetrate into the surface waters and thus phytoplankton productivity. Today, diatoms are the main primary producers in open waters of the Bellingshausen Sea (Fileman et al., 1998). This phytoplankton acts as food for zooplankton such as planktonic foraminifera which sink to form the core-top sediments. The general increase of IRD towards the core-top and the common manganese coating of gravel grains at the sediment surface strongly suggest that currents associated with the southern boundary of the ACC winnowed the outer shelf, slope and rise in the study area (cf. Hillenbrand et al., 2003). In combination with the resulting low sedimentation rate, which favours dissolution of siliceous microfossils on the seafloor, the winnowing process is likely to have enriched calcareous foraminifera tests on the seabed (Hillenbrand et al., 2003).

The clay mineral assemblages in the foraminiferal muds of cores PS2533 and PS2540 clearly represent a mixture of lithogenic material derived from both Eltanin Bay and Ronne Entrance (Fig. 4). The mixture can be explained by the activity of tidal and winddriven currents sweeping fine-grained detritus, which was primarily delivered to the sea by glaciers along the coast line, from the inner shelf to the outer shelf and slope. The same process affects the clay mineral assemblage in the foraminiferal mud at site PS2538, but here a prominent increase of chlorite is obvious, too. Probably, a westward flowing bottom current, which was detected on the continental rise west of the Antarctic Peninsula (Giorgetti et al., 2003 and references therein), extends to the western Bellingshausen Sea and advects a fine-grained suspension enriched in chlorite, which was supplied from the Antarctic Peninsula's mainland, to about $94^{\circ} \mathrm{W}$ (Hillenbrand et al., 2003).

\section{Summary and conclusions}

Upper Quaternary sediment cores recovered on the shelf, slope, and rise in the western Bellingshausen
Sea exhibit extremely similar lithological successions. Massive, homogenous diamictons at the base were deposited during the last glacial period and are overlain by thin-bedded lithogenic sandy muds deposited during the phase of glacial-interglacial transition. The top sediments are formed by bioturbated, foraminifer-bearing sediments. Despite their lithological similarities, the diamictons were deposited by different sedimentary processes, which we have reconstructed based on seafloor topography and on shear strength, clast concentration, biogenic content, and clay mineralogical composition of the diamictons. Accordingly, the diamictons on the slope and rise were deposited as GDFs, whereas those on the shelf were deposited as DT and GT, respectively.

The spatial relationship between the clay mineralogical fingerprints of the lithological units and the source areas in the hinterland, which are identified based on clay mineral assemblages of modern shelf sediments, allows the reconstruction of pathways for the lithogenic detritus, including the palaeo-flow paths of grounded ice. The comparison of the clay mineral assemblage of the GDFs with that of the DT and GT demonstrates that the GDFs were mainly fed by ice masses draining through Ronne Entrance, whereas the grounding line of an ice-stream tributary draining through Eltanin Bay only reached the outer shelf (at least during the late phase of the last glacial period).

Glaciomarine sedimentation under multiyear seaice/ice shelf coverage characterized the glacial-interglacial transition. On the slope and rise activity of turbidity currents denoted the retreat of grounded ice masses from the shelf. Deposition during the present interglacial was controlled by glaciomarine conditions with seasonal sea-ice coverage. Relatively high concentrations of planktonic foraminifera at the sediment surface result from winnowing processes, which accumulate coarse-grained particles and/or favour dissolution of siliceous tests by reducing sediment accumulation rates.

In order to distinguish glacial tills, glaciomarine tills, glaciogenic debris flows, and iceberg turbates in sediment cores recovered from a polar marine setting, we suggest that shear strength and clast concentration should be analyzed as well as the quantity and nature of microfossil content. Furthermore, inspection of the seafloor topography, at least regarding slope gradients and possible presence of iceberg furrows, represents a 
necessary prerequisite to evaluation of possible influences of sediment gravity flows and iceberg ploughing on shelf deposition. Mineralogical investigations of the diamicton's matrix (Anderson et al., 1980; Lowe and Anderson, 2002; this study) or petrological investigations of clasts within the diamictons (e.g. Pope and Anderson, 1992; King et al., 1998; Domack et al., 1999) as well as in the over- and underlying glaciomarine strata are essential not only for provenance analyses, but also for correct identification of depositional processes. As our study demonstrates that a genetic relationship between a till cored on the shelf and GDFs recovered on the adjacent margin cannot be considered to be proven without such investigations.

\section{Acknowledgements}

This work was supported by the Antarctic Funding Initiative programme of the National Environment Research Council (NERC), UK. We appreciate the kind assistance of the crews and masters of RV Polarstern and RRS James Clark Ross in collecting the samples. Furthermore, we thank F. Niessen (AWI) for logging the whole cores, M. Seebeck (AWI) for his assistance in core splitting, and W. Ehrmann (University of Leipzig) for analyzing the clay mineralogy of the samples recovered during JR104. We gratefully acknowledge the comments of C. Pudsey and R. Larter on an earlier draft, and the useful reviews of $\mathrm{J}$. Anderson and an anonymous reviewer.

\section{References}

Anderson, J.B., 1999. Antarctic Marine Geology. Cambridge University Press, Cambridge, UK. 289 pp.

Anderson, J.B., Kurtz, D.D., Domack, E.W., Balshaw, K.M., 1980. Glacial and glacialmarine sediments of the Antarctic continental shelf. J. Geol. 27, 399-414.

Anderson, J.B., Shipp, S.S., Lowe, A.L., Wellner, J.S., Mosola, A.B., 2002. The Antarctic ice sheet during the last glacial maximum and its subsequent retreat history: a review. Quat. Sci. Rev. 22, 49-70.

Bindschadler, R., 1998. Future of the West Antarctic Ice Sheet. Science 282, 428-429.

Canals, M., Casamor, J.L., Urgeles, R., Calafat, A.M., Domack, E.W., Baraza, J., Farran, M., DeBatist, M., 2002. Seafloor evidence of a subglacial sedimentary system off the northern Antarctic Peninsula. Geology 30, 603-606.

Diekmann, B., Fütterer, D.K., Grobe, H., Hillenbrand, C.-D., Kuhn, G., Michels, K., Petschick, R., Pirrung, M., 2003. Terrigenous sediment supply in the polar to temperate South Atlantic: landocean links of environmental changes during the Late Quaternary. In: Wefer, G., Mulitza, S., Ratmeyer, V. (Eds.), The South Atlantic in the Late Quaternary: Reconstruction of Material Budget and Current Systems. Springer, Berlin, pp. 375-399.

Domack, E., O’Brien, P., Harris, P., Taylor, F., Quilty, P.G., DeSantis, L., Raker, B., 1998. Late Quaternary sediment facies in Prydz Bay, East Antarctica and their relationship to glacial advance onto the continental shelf. Ant. Sci. 10, 236-246.

Domack, E.W., Jacobson, E.A., Shipp, S., Anderson, J.B., 1999. Late Pleistocene-Holocene retreat of the West Antarctic IceSheet system in the Ross Sea: Part 2. Sedimentologic and stratigraphic signature. Geol. Soc. Amer. Bull. 111, 1517-1536.

Doubleday, P.A., Leat, P.T., Alabaster, T., Nell, P.A.R., Tranter, T.H., 1994. Allochthonous Oceanic basalts within the Mesozoic accretionary complex of Alexander Island, Antarctica: remnants of Proto-Pacific oceanic crust. J. Geol. Soc. 151, 65-78.

Dowdeswell, J.A., Ó Cofaigh, C., Pudsey, C.J., 2004a. Thickness and extent of the subglacial till layer beneath an Antarctic paleoice stream. Geology 32, 13-16.

Dowdeswell, J.A., Ó Cofaigh, C., Pudsey, C.J., 2004b. Continental slope morphology and sedimentary processes at the mouth of an Antarctic palaeo-ice stream. Mar. Geol. 204, 203-214.

Ehrmann, W., Melles, M., Kuhn, G., Grobe, H., 1992. Significance of clay mineral assemblages in the Antarctic Ocean. Mar. Geol. $107,249-273$.

Elverhøi, A., Norem, H., Andersen, E.S., Dowdeswell, J.A., Fossen, I., Haflidason, H., Kenyon, N.H., Laberg, J.S., King, E.L., Sejrup, H.P., Solheim, A., Vorren, T., 1997. On the origin and flow behavior of submarine slides on deep-sea fans along the Norwegian-Barents Sea continental margin. Geo Mar. Lett. 17, $119-125$.

Evans, J., Pudsey, C.J., 2002. Sedimentation associated with Antarctic Peninsula ice shelves: implications for paleoenvironmental reconstructions of glacimarine sediments. J. Geol. Soc. 159, 233-237.

Evans, J., Pudsey, C.J., Ó Cofaigh, C., Morris, P., Domack, E., 2005. Late Quaternary glacial history, flow dynamics and sedimentation along the eastern margin of the Antarctic Peninsula ice sheet. Quat. Sci. Rev. 24, 741-774.

Eyles, N., Daniels, J., Osterman, L.E., Januszczak, N., 2001. Ocean Drilling Program Leg 178 (Antarctic Peninsula): sedimentology of glacially influenced continental margin topsets and foresets. Mar. Geol. 178, 135-156.

Fileman, T.W., Pond, D.W., Barlow, R.G., Mantoura, R.F.C., 1998. Vertical profiles of pigments, fatty acids and amino acids: evidence for undegraded diatomaceous material sedimenting to the deep ocean in the Bellingshausen Sea, Antarctica. Deep-Sea Res. I 45, 333-346.

Gee, M.J.R., Masson, D.G., Watts, A.B., Allen, P.A., 1999. The Saharan Debris Flow: an insight into the mechanics of long runout submarine debris flows. Sedimentology 46, 317-335. 
Giorgetti, A., Crise, A., Laterza, R., Perini, L., Rebesco, M., Camerlenghi, A., 2003. Water masses and bottom boundary layer dynamics above a sediment drift of the Antarctic Peninsula Pacific margin. Antarct. Sci. 15, 537-546.

Grobe, H., 1987. A simple method for the determination of icerafted debris in sediment cores. Polarforschung 57, 123-126.

Hillenbrand, C.-D., Ehrmann, W., 2002. Distribution of clay minerals in drift sediments on the continental rise west of the Antarctic Peninsula, ODP Leg 178, Sites 1095 and 1096. In: Barker, P.F., Camerlenghi, A., Acton, G.D., Ramsay, A.T.S. (Eds.), Proceedings of the Ocean Drilling Program, Scientific Results, vol. 178. Ocean Drilling Program, Texas A\&M University, College Station, pp. 1-29. CD-ROM.

Hillenbrand, C.-D., Ehrmann, W., 2003. Palaeoenvironmental implications from Tertiary sediments sf Kainan Maru Seamount and Northern Gunnerus Ridge. Antarct. Sci. 15, $522-536$.

Hillenbrand, C.-D., Fütterer, D.K., Grobe, H., Frederichs, T., 2002. No evidence for a Pleistocene collapse of the West Antarctic Ice Sheet from continental margin sediments recovered in the Amundsen Sea. Geo Mar. Lett. 22, 51-59.

Hillenbrand, C.-D., Grobe, H., Diekmann, B., Kuhn, G., Fütterer, D., 2003. Modern glaciomarine environment and its sedimentary record in the Bellingshausen and Amundsen Seas (West Antarctica). Mar. Geol. 193, 253-271.

Igarashi, A., Numanami, H., Tsuchiya, Y., Fukuchi, M., 2001. Bathymetric distribution of fossil foraminifera within marine sediment cores from the eastern part of Lützow-Holm Bay, East Antarctica, and its paleoceanographic implications. Mar. Micropaleontol. 42, 125-162.

Ishman, S.E., Domack, E.W., 1994. Oceanographic control on benthic foraminifers from the Bellingshausen margin of the Antarctic Peninsula. Mar. Micropaleontol. 24, 119-155.

Jacobs, S.S., Hellmer, H.H., Jenkins, A., 1996. Antarctic Ice Sheet melting in the Southeast Pacific. Geophys. Res. Lett. 23, 957-960.

Kellogg, T.B., Kellogg, D.E., 1988. Antarctic cryogenic sediments: biotic and inorganic facies of ice shelf and marine-based ice sheet environments. Palaeogeogr. Palaeoclimatol. Palaeoecol. $67,51-74$.

King, E.L., Haflidason, H., Sejrup, H.P., Løvlie, R., 1998. Glacigenic debris flows on the North Sea Trough Mouth Fan during ice stream maxima. Mar. Geol. 152, 217-246.

Kurtz, D.D., Anderson, J.B., 1979. Recognition and sedimentologic description of recent debris flow deposits from the Ross and Weddell seas, Antarctica. J. Sediment. Petrol. 49, 1159-1170.

Laberg, J.S., Vorren, T.O., 2000. Flow behaviour of the submarine glacigenic debris flows on the Bear Island Trough Mouth Fan, western Barents Sea. Sedimentology 47, 1105-1117.

Laberg, J.S., Vorren, T.O., Mienert, J., Evans, D., Lindberg, B., Ottese, D., Kenyon, N.H., Henriksen, S., 2002. Late Quaternary palaeoenvironment and chronology in the Trænadjupet Slide area offshore Norway. Mar. Geol. 188, 35-60.

Larter, R.D., Cunningham, A.P., 1993. The depositional pattern and distribution of glacial-interglacial sequences on the Antarctic Peninsula Pacific Margin. Mar. Geol. 109, 203-219.
Larter, R.D., Dowdeswell, J.A., Pudsey, C.J., Evans, J., Hillenbrand, C.-D., Morris, P., Ó Cofaigh, C., 2004. Investigations of a major palaeo-outlet of the West Antarctic Ice Sheet in the southern Bellingshausen Sea: preliminary results from RRS "James Clark Ross" cruise JR104 (Abstract). SCAR Open Science Conference "Antarctica and the Southern Ocean in the Global System”, Bremen 25-31 July 2004, Terra Nostra 2004, p. 252.

Laudon, T.S., 1991. Petrology of sedimentary rocks from the English Coast, eastern Ellsworth Land. In: Thomson, M.R.A., Crame, J.A., Thomson, J.W. (Eds.), Geological Evolution of Antarctica. Cambridge University Press, Cambridge, UK, pp. 455-460.

Li, B., Yoon, H.-I., Parka, B.-K., 2000. Foraminiferal assemblages and $\mathrm{CaCO}_{3}$ dissolution since the last deglaciation in the Maxwell Bay, King George Island, Antarctica. Mar. Geol. $169,239-257$.

Licht, K.J., 2004. The Ross Sea's contribution to eustatic sea level during Meltwater Pulse 1a. Sediment. Geol. 165, 343-353.

Licht, K.J., Dunbar, N.W., Andrews, J.T., Jennings, A.E., 1999. Distinguishing subglacial till and glacial marine diamictons in the western Ross Sea, Antarctica: implications for a Last Glacial Maximum grounding line. Geol. Soc. Amer. Bull. 111, $91-103$.

Lowe, A.L., Anderson, J.B., 2002. Late Quaternary retreat of the West Antarctic Ice Sheet in Pine Island Bay, Antarctica. Quat. Sci. Rev. 21, 1879-1897.

Mackensen, A., Grobe, H., Kuhn, G., Fütterer, D.K., 1990. Benthic foraminiferal assemblages from the eastern Weddell Sea between $68^{\circ}$ and $73^{\circ} \mathrm{S}$ : distribution, ecology and fossilization potential. Mar. Micropaleontol. 16, 241-283.

McCarron, J.J., Smellie, J.L., 1998. Tectonic implications of forearc magmatism and generation of high-magnesian andesites: Alexander Island, Antarctica. J. Geol. Soc. 155, 269-280.

Milam, R.W., Anderson, J.B., 1981. Distribution and ecology of recent benthonic foraminifera of the Adélie-George $\mathrm{V}$ continental shelf and slope, Antarctica. Mar. Micropaleontol. 6, $297-325$.

Miller, H., Grobe, H. (Eds.), (1996). Die Expedition Antarktis-XI/3 mit FS "Polarstern" 1994. Rep. Polar Res., vol. 188. Alfred Wegener Institute for Polar and Marine Research, Bremerhaven. 115 pp.

Nitsche, F.O., Gohl, K., Vanneste, K., Miller, H., 1997. Seismic expression of glacially deposited sequences in the Bellingshausen and Amundsen seas, West Antarctica. In: Barker, P.F., Cooper, A.K. (Eds.), Geology and Seismic Stratigraphy of the Antarctic Margin, Part 2. Antarct. Res. Ser., vol. 71. American Geophysical Union, Washington, DC, pp. 95-108.

Nitsche, F., Cunningham, A., Larter, R., Gohl, K., 2000. Geometry and development of glacial continental margin depositional systems in the Bellingshausen Sea. Mar. Geol. 162, 277-302.

Nygård, A., Sejrup, H.P., Haflidason, H., King, E.L., 2002. Geometry and genesis of glacigenic debris flows on the North Sea Fan: TOBI imagery and deep-tow boomer evidence. Mar. Geol. 188, 15-33. 
Ó Cofaigh, C., Pudsey, C.J., Dowdeswell, J.A., Morris, P., 2002. Evolution of subglacial bedforms along a paleo-ice stream, Antarctic Peninsula continental shelf. Geophys. Res. Lett. 29.

Ó Cofaigh, C., Dowdeswell, J.A., Larter, R., Pudsey, C.J., Hillenbrand, C.-D., Evans, J., Morris, P., 2004. Late Quaternary ice-sheet dynamics in the southern Bellingshausen Sea as reconstructed from marine geophysical evidence (Abstract). Interdisciplinary Workshop "Antarctic Peninsula Climate Variability: History, Causes and Impacts", Cambridge, UK, September 16-18, 2004, p. 48

Ó Cofaigh, C., Dowdeswell, J.A., Allen, C.S., Hiemstra, J.F., Pudsey, C.J., Evans, J., Evans, D.J.A., 2005. Flow dynamics and till genesis associated with a marine-based Antarctic palaeo-ice stream. Quat. Sci. Rev. 24, 709-740.

Ó Cofaigh, C., Larter, R., Dowdeswell, J.A., Hillenbrand, C.-D., Pudsey, C.J., Evans, J., Morris, P., submitted for publication. Flow of the West Antartic Ice Sheet on the continental margin of the Bellingshausen Sea at the Last Glacial Maximum. J. Geophys. Res.

Orsi, A.H., Whitworth III, T., Nowlin Jr., W.D., 1995. On the meridional extent and fronts of the Antarctic circumpolar current. Deep-Sea Res. I 42, 641-673.

Petschick, R., Kuhn, G., Gingele, F.X., 1996. Clay mineral distribution in surface sediments of the South Atlantic: sources, transport, and relation to oceanography. Mar. Geol. 130, 203-229.

Pope, P.G., Anderson, J.B., 1992. Late Quaternary glacial history of the northern Antarctic Peninsula's western continental shelf: evidence from the marine record. In: Elliott, D.H. (Ed.), Contributions to Antarctic Research III. Antarct. Res. Ser., vol. 57. American Geophysical Union, Washington, DC, pp. 63-91.

Pudsey, C.J., Barker, P.F., Larter, R.D., 1994. Ice Sheet retreat from the Antarctic Peninsula shelf. Cont. Shelf Res. 14, 1647-1675.

Pudsey, C.J., Evans, J., Domack, E.W., Morris, P., Del Valle, R.A., 2001. Bathymetric and acoustic facies beneath the former Larsen-A and Prince Gustav ice shelves, north-west Weddell Sea. Antarct. Sci. 13, 312-322.

Robert, C., Maillot, H., 1990. Palaeoenvironments in the Weddell Sea area and Antarctic climates, as deduced from clay mineral associations and geochemical data, ODP Leg 113. In: Barker, P.F., Kennett, J.P., et al., (Eds.), Proceedings of the Ocean Drilling Program. Scientific Results, vol. 113. Ocean Drilling Program, Texas A\&M University, College Station, pp. 51-66.
Rowley, P.D., Kellogg, K.S., Vennum, W.R., Laudon, T.S., Thomson, J.W., O’Neill, J.M., Lidke, D.J., 1991. Tectonic setting of the English Coast, eastern Ellsworth Land, Antarctica. In: Thomson, M.R.A., Crame, J.A., Thomson, J.W. (Eds.), Geological Evolution of Antarctica. Cambridge University Press, Cambridge, UK, pp. 467-473.

Sættem, J., Poole, D.A.R., Ellingsen, L., Sejrup, H.P., 1992. Glacial geology of outer Bjørnøyrenna, southwestern Barents Sea. Mar. Geol. 103, 15-51.

Scherer, R.P., Sjunneskog, C.M., Iverson, N.R., Hooyer, T.S., 2004. Assessing subglacial processes from diatom fragmentation patterns. Geology 32, 557-560.

Schwab, W.C., Lee, H.J., Twichell, D.C., Locat, J., Nelson, H.C., Mcarthur, M., Kenyon, N.H., 1996. Sediment mass-flow processes on a depositional lobe, outer Mississippi Fan. J. Sediment. Res. 66, 916-927.

Shipp, S., Anderson, J., Domack, E., 1999. Late PleistoceneHolocene retreat of the West Antarctic Ice-Sheet system in the Ross Sea: Part 1. Geophysical results. Geol. Soc. Amer. Bull. 111, 1486-1516.

Smellie, J.L., 1999. Lithostratigraphy of Miocene-recent, alkaline volcanic fields in the Antarctic Peninsula and eastern Ellsworth Land. Antarct. Sci. 11, 362-378.

Stow, D.A.V., 1994. Deep sea processes of sediment transport and deposition. In: Pye, K. (Ed.), Sediment Transport and Depositional Processes. Blackwell Scientific Publications, Oxford, pp. 257-291.

Vennum, W.R., Nejedly, J.W., 1990. Clay mineralogy of soils developed on weathered igneous rocks, West Antarctica. N.Z. J. Geol. Geophys. 33, 579-584.

Vorren, T.O., Hald, M., Thomsen, E., 1984. Quaternary sediments and environments on the continental shelf off northern Norway. Mar. Geol. 57, 229-257.

Wellner, J.S., Lowe, A.L., Shipp, S.S., Anderson, J.B., 2001. Distribution of glacial geomorphic features on the Antarctic continental shelf and correlation with substrate: implications for ice behavior. J. Glaciol. 47, 397-411.

Wright, R., Anderson, J.B., 1982. The importance of sediment gravity flow to sediment transport and sorting in a glacial marine environment: eastern Weddell Sea. Geol. Soc. Amer. Bull. 93, $951-963$. 